\title{
Implementation of Problem Based Learning Methods in Student Spelling Learning
}

\author{
Fransisca Dwi Harjanti ${ }^{1}$ \\ Ni Luh Ramayani ${ }^{2}$ \\ ${ }^{1}$ Universitas Wijaya Kusuma Surabaya \\ ${ }^{2}$ SMA Hang Tuah 4 Surabaya
}

\begin{abstract}
ABSTRAK
Saat ini pada kurikulum Bahasa Indonesia, khususnya yang digunakan di jenjang pendidikan Sekolah Menengah Atas kelas X IPA, satu di antara kompetensi dasar yang dibahas adalah menulis teks laporan hasil observasi. Di dalam menulis laporan teks hasil observasi diperlukan kemampuan bidang kebahasaan, khususnya kemampuan menggunakan ejaan. Untuk memberikan pemahaman yang baik kepada para siswa tentang ejaan diperlukan strategi khusus. Strategi yang bisa digunakan untuk menggali kompetensi peserta didik di bidang ejaan adalah problem based learning. Dalam strategi ini siswa dituntut lebih aktif dan kreatif dalam menyelesaikan permasalahan yang diberikan guru. Strategi ini diterapkan pada peserta didik kelas X IPA 2 di SMA Hang Tuah 4 Surabaya. Setelah diterapkan pembelajaran yang berbasis problem based learning diperoleh hasil bahwa rata-rata kemampuan siswa dalam memahami ejaan di atas $75 \%$. Hanya sebagian kecil kelompok yang kemampuannya di bawah $75 \%$. Kesalahan yang paling banyak dilakukan siswa adalah dalam menggunakan tanda baca koma (,). Kesalahan yang paling sedikit dilakukan adalah pengunaan tanda baca titik (.)
\end{abstract}

Kata Kunci : Problem Based Learning, tanda baca, huruf kapital, kata depan

\begin{abstract}
In the Indonesian Language curriculum, especially those in the Indonesian Language curriculum used at the High School level of Class X Science, one of the basic competencies discussed is writing the observation report text. In writing a text report the results of observation require the ability of the language field, specifically the ability to use spelling. To give students a good understanding of spelling, special strategies are needed. Strategies that can be used to explore students' competencies in the spelling field are problem based learning. In this strategy students are required to be more active and creative in solving problems given by the teacher. This strategy is applied to students of Class X Science 2 at Hang Tuah 4 Surabaya High School. After applying problem-based learning based on the results obtained that the average ability of students in understanding spelling is above $75 \%$. Only a small proportion of groups whose ability is under $75 \%$. The most mistake students make is in using comma (,) punctuation. The least mistake made is the use of period punctuation (.).
\end{abstract}

Keywords: Problem Based Learning, punctuation, capital letters, prepositions.

\section{INTRODUCTION}

In the secondary education curriculum, especially in high school writing skills are given starting from class $\mathrm{X}$ to XII. The skills provided include writing report observation text, writing exposition text, anecdotal text, critical procedure text, and others. Especially for class X IPA semester I, the material of writing skills includes writing the text of the observation report. One of the basic competencies (KD) in writing report observational text is constructing the observation report text by paying attention to the contents and linguistic aspects both verbally and in writing (Indonesian Syllabus Class X IPA).

In this activity, students are asked to make observations / observations on the environment 
and then write down the results of their observations in written form. In reporting the results of their observations in written form there are several provisions that students need to pay attention to namely the language rules. The linguistic rules in question include sentence use, word choice, and spelling. As expressed by Suparno (2003: 5) that in writing activities a person must have skills including applying spelling, choosing words correctly, arranging sentences effectively, using paragraphs by paying attention to coherence and cohesion, and the ability to express ideas in a discourse .

In writing activities, the use of language rules needs to be considered keeping in mind that writing reports (observational texts) is the result of scientific writing. A distinctive feature of scientific papers is the correct use of Indonesian languages by taking into account the rules of using standard languages. Indonesian is the correct use in accordance with the rules of grammar in arranging sentences, choosing words, and spelling. Thus the learning of writing skills in schools, especially middle schools cannot be separated from the linguistic aspects. As Yulianto (2008: 7) found that language learning in schools must be more oriented towards learning language skills, not language learning. Thus learning should be directed at practicing real language, for example through writing activities.

In learning language skills, especially writing skills, teachers should always remind students to always pay attention to the rules / aspects of language. Yulianto (2008: 7) reminded teachers that learning aspects of language is not only done when teachers find language errors in students. Thus the learning aspects of language become less structured. So that learning aspects of language becomes a habit, the teacher needs to form and remind when students are not appropriate in language.

In the secondary education curriculum, especially the curriculum used at the Senior High School level, Indonesian subjects, linguistic material, especially spelling is given in the first semester of class X IPA. This material is included in the material analyzing the linguistic elements of writing Observation Report text. To facilitate students' understanding of linguistic material, especially spelling, an effective and efficient learning approach is needed. Among the learning methods that provide meaningful learning experiences for students, especially students of class X IPA 1 at SMA Hang Tuah 4 Surabaya is a problem based approach or problem base learning. In the General Guidelines for Indonesian Spelling, the spelling problems include the use of letters, writing words, and using punctuation.

According to Barrow (in Huda, 2014: 271) problem-based learning (problem base learning ( PBL) is learning that is obtained through a process leading to an understanding of the resolution of a problem that is met through the learning process. Problem Base Learning focuses on student learning not teacher teaching. Thus learning is focused on students. Students who have an active involvement in the learning process. Furthermore it is said that there are three basic elements at the time of PBL implementation, namely initiating triggers / problems, examining issues identified previously, and utilizing knowledge in understanding the problem situation. The steps in learning using themethod problem base learning include the following. First, students are arranged in such a way (preferably in groups) then a problem is presented. Second, students discuss the problems that have been given in a small group. Third, students are involved in independent studies to solve problems outside the teacher's guidance. Fourth, students return to the PBL tutorial to exchange information on certain problems. Fifth, students present solutions to problems that are solved. Sixth, the students do aof review what they have learned, and all are involved in Revier, personal Revier pairs based on the guidance of teachers.

Based on the description in front. This paper explains the learning process in class using themethod problem based learning. This 
method will be implemented in Indonesian language materials (spelling) for Class X IPA 1 students at Hang Tuah 4 Surabaya. Material on spelling includes the use of punctuation, capital letters, prepositions.

\section{METHODE}

\section{Method Problem Based Learning in Learning in Class}

To implement the method of method, problem based learning it is necessary to compile the steps of implementing learning in class. As stated by Ibrahim (2000) in Rusman (2012: 243) that there are several steps that need to be done by teachers in PBL classes. These steps include student orientation to the problem, organizing students to learn, guiding individual or group experiences, developing and presenting their work, and analyzing and evaluating the problem solving process. In student orientation activities on problems, the teacher explains the learning objectives and motivates students to be involved in problem solving activities. In organizing students to learn, the teacher's job is to help students organize learning tasks related to the problem. In mentoring activities, the teacher's task is to encourage students to gather information, carry out experiments in solving problems, In developing activities and presenting the work of the teacher's assignments is to help students plan and prepare appropriate work and help to share assignments with friends. In evaluating the problem solving process, the teacher's job is to help students to reflect or evaluate the problem solving they use. For this reason, the following is a brief description of the implementation of learning in the PBL class

\section{RESULTS AND DISCUSSION}

Basic Competency: analyzing the linguistic aspects of the observation report text. Competency Achievement Indicators: Students can improve the spelling contained in the discourse and can use it in writing observational text reports.
Classroom Learning Activities: The

1. Teacher prepares students in such a way by arranging seating. Seating arrangements are related to group arrangements. Because in one bench consists of two people, each group consists of two people. In this case students are given the freedom to choose their friends who will become members of the group.

2. The teacher prepares four examples of discourse that are missing punctuation marks. These discourses were given to each group. Each group is allowed to choose two of the four discourses prepared by the teacher. The two discourses that have been selected by each group will be a problem that must be solved by students.

3. In this small group students begin to discuss the problems that have been given by the teacher. Each student is actively involved to solve problems regarding spelling. In this case students are given the opportunity to get information from various sources to solve the problem. Students can use their cellphones through the internet or to the library.

4. The three activities in front were held in one meeting for 80 minutes. At the next meeting after students solve the problems that are their respective assignments, the teacher asks students to return to their respective groups to review their assignments together with members of the group.

5. Students present the results of the review together with group members in the presence of other group members. In this activity the teacher's task is only as a facilitator who guides students if they experience difficulties. After everything presents their work, students return to their groups to re-review their assignments. This reviewer is based on input from other group members and teachers.

6. As an enrichment material the teacher provides different discourses that students can do at home. The work will be discussed 
together with the teacher at the next meeting. When working on assignments at home students use knowledge about spelling that was previously obtained at school. Thus the hope is students no longer need to find information from various sources to solve the problem.

7. All spelling knowledge is used by students as a basis for writing observational report texts.

discussion:

Examples of discourse as baham

1. At a very young age darmanto is well known as a celebrity his art blood was obtained because of natural talent and has a line from the almighty from young to his old age darmanto still wrestle fiddling with language as a means of writing poetry because Darmanto deserves to be called as a poet with a myriad of poems and at the same time a myriad of achievements hundreds of poetry and scattered in various mass media and publishing for his achievements in the arts Darmanto lowered his art blood to his children umi diamond naomi, abigail wohing ati, orange flowers, character, aryaning aryo krishna and gautama jatining sesami darmanto children and even then carved achievements in the field of literary and artistic work

2. Wanagalih is a district capital even though the city is an old capital that was present since the mid-19th century the city looks small and just like its old age that's ti did not give him the opportunity to grow and develop, of course, large, shady tamarind trees that lined the highway that divides the city that I was familiar with very well in my childhood had ceased to exist and replaced with acacia trees that looked slimmer of course the market at the center the city has been chopped up with a series of kiosks that encircle the market so that from the outside it looks like a new style small shopping center but behind the stalls and shops in the market people still sell goods that have always been present there and that I have known familiarly since my childhood

3. Natalia a teenage girl loves her pets every morning she takes her dog for a walk she feeds her two dogs and the three cats she raises she cleans a parrot she just bought from the market after she finishes feeding the bird when the sun has emitted the parrots sun dried in the cells ama one hour after the job of taking care of his pet job he had breakfast in thekitchen

4. Poorreally andini's fate the six-month-old baby was July 2, then died after suffering from skin diseases all over his body andini was not like a baby most of his body skin peeling from head to foot the condition suffered Since birth, besides Andini, dozens of residents of Buyat Beach were also affected by a lump in their bodies, dizzy and quickly fatigued after gold mining company PT Newmont Minahasa Raya operated in Buyat, finally last week a number of local residents, including Ibu Andini Masnah Stirman, complained about the impact of their Newmont waste disposal. even complained to Jakarta

\section{Student Mastery of Spelling}

To find out how far students understand the spelling of the material to write the text of the report on the results of the observation, below this table is presented a percentage of students' mastery in understanding spelling. 
Discourse 1:

\begin{tabular}{|c|c|c|c|c|c|c|c|c|}
\hline \multirow{2}{*}{$\begin{array}{l}\text { No } \\
\text { Ex }\end{array}$} & \multirow[t]{2}{*}{ Name of Student } & \multicolumn{2}{|c|}{ Use Punctuation } & \multirow{2}{*}{$\begin{array}{l}\text { The } \\
\text { Uppercase }\end{array}$} & \multirow{2}{*}{$\begin{array}{l}\text { Preposition } \\
\text { Writing }\end{array}$} & \multirow{2}{*}{$\begin{array}{l}\text { Number } \\
\text { of error }\end{array}$} & \multirow{2}{*}{$\begin{array}{l}\text { Percent } \\
(\%) \\
\text { error }\end{array}$} & \multirow{2}{*}{$\begin{array}{l}\text { Percent } \\
\% \text { ) } \\
\text { mastery }\end{array}$} \\
\hline & & & Semicolon & & & & & \\
\hline \multirow[t]{2}{*}{1} & Karen Kalisa & \multirow[t]{2}{*}{1} & \multirow[t]{2}{*}{4} & \multirow[t]{2}{*}{0} & \multirow[t]{2}{*}{1} & \multirow[t]{2}{*}{6} & \multirow[t]{2}{*}{24} & \multirow[t]{2}{*}{76} \\
\hline & Liza Oktarita & & & & & & & \\
\hline \multirow[t]{2}{*}{2} & Rahmat & \multirow[t]{2}{*}{2} & \multirow[t]{2}{*}{1} & \multirow[t]{2}{*}{2} & \multirow[t]{2}{*}{1} & \multirow[t]{2}{*}{6} & \multirow[t]{2}{*}{24} & \multirow[t]{2}{*}{76} \\
\hline & Alvin A & & & & & & & \\
\hline \multirow[t]{2}{*}{3} & Aprilia E & \multirow[t]{2}{*}{1} & 2 & 0 & 3 & 6 & 24 & 76 \\
\hline & Paquita A & & & & & & & \\
\hline 4 & Fikri Wahyu & 0 & 0 & 0 & 2 & 2 & 8 & 92 \\
\hline & Rifani & & & & & & & \\
\hline 5 & M Iqbal & 0 & 3 & 0 & 4 & 7 & 28 & 72 \\
\hline & Ananda M & & & & & & & \\
\hline 6 & Rizal BR & 1 & 3 & 2 & 2 & 8 & 32 & 68 \\
\hline & Valentino Y & & & & & & & \\
\hline 7 & Dinda Maharani & 0 & 2 & 0 & 2 & 4 & 16 & 84 \\
\hline & Tsbitah Oktabila & & & & & & & \\
\hline 8 & Arya Kusuma N & 0 & 0 & 1 & 0 & 1 & 4 & 96 \\
\hline & Eka Adiliya P & & & & & & & \\
\hline 9 & Siera Sprott & 0 & 2 & 3 & 0 & 5 & 20 & 80 \\
\hline & Sonia Puspita & & & & & & & \\
\hline 10 & Amanda PU & 0 & 2 & 0 & 2 & 4 & 16 & 84 \\
\hline & Ika Naya G & & & & & & & \\
\hline 11 & M Firdaus GDS & 0 & 1 & 1 & 0 & 2 & 8 & 92 \\
\hline & Reihan Dial SS & & & & & & & \\
\hline 12 & Nandina Salsabilla & 3 & 1 & 2 & 0 & 6 & 24 & 76 \\
\hline & Marisa Puspa & & & & & & & \\
\hline & Umi Salasatun & & & & & & & \\
\hline 13 & Kinanti Adelia & 0 & 0 & 3 & 0 & 3 & 12 & 88 \\
\hline & Shofiana Islami & & & & & & & \\
\hline 14 & Dimas Riski S & 0 & 0 & 0 & 1 & 1 & 4 & 96 \\
\hline & Willy Arie A & & & & & & & \\
\hline 15 & Azzahra Istighfaria & 1 & 0 & 0 & 0 & 1 & 4 & 96 \\
\hline & Resy May & & & & & & & \\
\hline 16 & Anatha Fillia P & 0 & 2 & 0 & 3 & 5 & 20 & 80 \\
\hline & Dinda Nafas Islami & & & & & & & \\
\hline 17 & Aquilah Putri R & 1 & 0 & 0 & 0 & 1 & 4 & 96 \\
\hline & Syauqita $\mathrm{S}$ & & & & & & & \\
\hline & Total & 10 & 23 & 14 & 21 & & & \\
\hline
\end{tabular}

Discourse 2:

\begin{tabular}{|c|c|c|c|c|c|c|c|c|}
\hline \multirow{2}{*}{$\begin{array}{l}\text { No. } \\
\text { Ex }\end{array}$} & \multirow{2}{*}{ Student Name } & \multicolumn{2}{|c|}{ Use Punctuation } & \multirow{2}{*}{ Uppercase } & \multirow{2}{*}{$\begin{array}{l}\text { Preposition } \\
\text { Writing }\end{array}$} & \multirow{2}{*}{$\begin{array}{l}\text { Number } \\
\text { of error }\end{array}$} & \multirow{2}{*}{$\begin{array}{l}\text { Percent } \\
\text { (error) }\end{array}$} & \multirow{2}{*}{$\begin{array}{l}\text { Percent } \\
\text { (Mastery) }\end{array}$} \\
\hline & & & Semicolon & & & & & \\
\hline \multirow[t]{2}{*}{1} & Karen Kalisa & \multirow[t]{2}{*}{0} & \multirow[t]{2}{*}{2} & \multirow[t]{2}{*}{0} & \multirow[t]{2}{*}{0} & \multirow[t]{2}{*}{2} & \multirow[t]{2}{*}{8} & \multirow[t]{2}{*}{92} \\
\hline & Liza Oktarita & & & & & & & \\
\hline \multirow[t]{2}{*}{2} & Rahmat & \multirow[t]{2}{*}{0} & \multirow[t]{2}{*}{2} & \multirow[t]{2}{*}{0} & \multirow[t]{2}{*}{1} & \multirow[t]{2}{*}{3} & \multirow[t]{2}{*}{12} & \multirow[t]{2}{*}{88} \\
\hline & Alvin A & & & & & & & \\
\hline
\end{tabular}




\begin{tabular}{|c|c|c|c|c|c|c|c|c|}
\hline \multirow[t]{2}{*}{3} & Aprilia E & \multirow[t]{2}{*}{0} & \multirow[t]{2}{*}{1} & \multirow[t]{2}{*}{0} & \multirow[t]{2}{*}{1} & \multirow[t]{2}{*}{2} & \multirow[t]{2}{*}{8} & \multirow[t]{2}{*}{92} \\
\hline & Paquita A & & & & & & & \\
\hline \multirow[t]{2}{*}{4} & Fikri Wahyu & \multirow[t]{2}{*}{1} & \multirow[t]{2}{*}{1} & \multirow[t]{2}{*}{0} & \multirow[t]{2}{*}{0} & \multirow[t]{2}{*}{2} & \multirow[t]{2}{*}{8} & \multirow[t]{2}{*}{92} \\
\hline & Rifani & & & & & & & \\
\hline \multirow[t]{2}{*}{5} & M Iqbal & \multirow[t]{2}{*}{0} & \multirow[t]{2}{*}{2} & \multirow[t]{2}{*}{0} & \multirow[t]{2}{*}{1} & \multirow[t]{2}{*}{3} & \multirow[t]{2}{*}{12} & \multirow[t]{2}{*}{88} \\
\hline & Ananda M & & & & & & & \\
\hline \multirow[t]{2}{*}{6} & Rizal BR & \multirow[t]{2}{*}{0} & \multirow[t]{2}{*}{2} & \multirow[t]{2}{*}{0} & \multirow[t]{2}{*}{2} & 4 & 16 & 84 \\
\hline & Valentino Y & & & & & & & \\
\hline 7 & Dinda Maharani & 0 & 1 & 0 & 0 & 1 & 4 & 96 \\
\hline & Tsbitah Oktabila & & & & & & & \\
\hline 8 & Arya Kusuma N & 1 & 3 & 2 & 0 & 6 & 24 & 76 \\
\hline & Eka Adiliya P & & & & & & & \\
\hline 9 & Siera Sinta & 0 & 2 & 0 & 2 & 4 & 16 & 84 \\
\hline & Sonia Puspita & & & & & & & \\
\hline 10 & Amanda PU & 0 & 0 & 0 & 1 & 1 & 4 & 96 \\
\hline & Ika Naya G & & & & & & & \\
\hline 11 & M Firdaus GDS & 2 & 0 & 2 & 2 & 6 & 24 & 76 \\
\hline & Reihan Dial SS & & & & & & & \\
\hline 12 & Nandina & 1 & 2 & 4 & 1 & 8 & 32 & 68 \\
\hline & Umi Salasatun & & & & & & & \\
\hline & Marisa Puspa & & & & & & & \\
\hline 13 & Kinanti Adelia & 0 & 0 & 0 & 0 & 0 & 0 & 100 \\
\hline & Shofiana Islami & & & & & & & \\
\hline 14 & Dimas Riski S & 1 & 2 & 4 & 1 & 8 & 32 & 68 \\
\hline & Willy Arie A & & & & & & & \\
\hline 15 & $\begin{array}{l}\text { Azzahra } \\
\text { Istighfaria }\end{array}$ & 1 & 1 & 0 & 0 & 2 & 8 & 92 \\
\hline & Resy May & & & & & & & \\
\hline 16 & Anatha Fillia P & 1 & 0 & 0 & 1 & 2 & 8 & 92 \\
\hline & $\begin{array}{l}\text { Dinda } \\
\text { Islami }\end{array}$ & & & & & & & \\
\hline 17 & Aquilah & 0 & 0 & 0 & 1 & 1 & 4 & 96 \\
\hline & Syauqita $S$ & & & & & & & \\
\hline & Total & 8 & 21 & 12 & 14 The & & & \\
\hline
\end{tabular}

table in front illustrates the percentage of students' mastery in understanding spelling. This percentage can be seen from the number of mistakes made by each group. These errors include the placement of dot punctuation, comma punctuation, use of capital letters, and writing prepositions. From the table above it can be seen that the average mastery in understanding spelling is above $75 \%$. In table 1 only one group has mastery below $75 \%$, namely group six, whereas in table 2 there are two groups whose mastery is below $75 \%$, namely groups twelve and fourteen. Judging from the number of errors in the use of spelling, from the two tables in front it can be illustrated that many errors occur in the use of comma (,) punctuation, while for dot punctuation (.) The error rate is less than the other spelling.

\section{CONCLUSION}

Learning methods based on problems or problem based learning can be used in the learning process that requires active and creative student involvement. In learning to write report texts the results of observation of linguistic material (spelling) of the learning 
process can be carried out using themethod problem based learning. The learning process starts from the problems given to students, problem solving, until the process of reporting the results of the discussion of the students all done collaboratively. After analyzing the data it can be concluded that a large portion ie above $75 \%$ of students can use spelling correctly in the given discourse.

\section{REFERENCES}

Huda, Miftahul. 2014. Teaching and Learning Models: Methodical and Paradigmatic Issues. Yogyakarta: Student Library.
Indonesian Curriculum for Class XSciences

Natural Rusman. 2012. Learning Models:

Developing Teacher Professionalism.

Jakarta: Rajawali Press.

Suparno and Yunus. 2003. Basic Writing Skills.Jakarta: Open University.

Indonesian Language Guides Development Team. 2016. General Guidelines for Indonesian Spelling. Jakarta: Indonesian Language Development and Coaching Agency.

Yulianto, Bambang. 2008. Language Aspects and Learning. Surabaya: Surabaya State University. 